\title{
FAKTOR-FAKTOR TERKAIT TINGKAT KEPARAHAN INFEKSI CORONAVIRUS DISEASE 2019 (COVID-19): SEBUAH KAJIAN LITERATUR
}

\author{
Abiyyu Didar Haq', Adli Putra Nugraha', Febby Anggy', Fiana Damayanti', I Komang \\ Gede Andhika Wibisana', Ni Putu Visty Widhiani', R.R Ditya Mutiara Syifa', \\ Cut Warnaini ${ }^{\star_{2}}$ \\ Program Studi Pendidikan Dokter Fakultas Kedokteran Universitas Mataram \\ 2Departemen Ilmu Kesehatan Masyarakat, Fakultas Kedokteran Universitas Mataram
}

\begin{abstract}
ABSTRAK
Korespondensi:

Cut Warnaini

Email author:

cut.warnaini@unram.ac.id

Riwayat Artikel

Diterima: 19 Maret 2021

Selesai revisi: 8 Juni 2021

DOI :

10.53366/jimki.v9i1.338

Pendahuluan: Pandemi penyakit virus corona (COVID-19) yang mulai mewabah pada awal tahun 2020 memicu ditetapkannya Public Health Emergency of International Concern (PHEIC) oleh WHO. Disebabkan oleh SARS-CoV-2, COVID-19 utamanya menginfeksi sistem pernafasan dengan menempel pada reseptor ACE2. Infeksi COVID-19 menyebabkan beragam manifestasi klinis mulai tanpa gejala hingga gejala berat yang mengancam nyawa, bergantung pada berbagai faktor. Berbagai faktor yang mampu menentukan berat-ringannya manifestasi klinis yang ditimbulkan oleh infeksi COVID-19 sangat perlu diperhatikan oleh klinisi sehingga mampu mengantisipasi kondisi pasien sebelum manifestasi klinis tersebut muncul. Kajian literatur ini bertujuan untuk membahas dan merangkum berbagai literatur terkait beberapa faktor yang dinilai paling menentukan tingkat keparahan infeksi COVID-19.

Metode: Kajian literatur ini menggunakan berbagai artikel jurnal yang didapatkan dari pusat data daring yaitu PubMed dan Google Scholar. Artikel yang dipilih berupa artikel penelitian, systematic review dan metaanalysis, serta narrative review terfokus pada transmisi, manifestasi klinis, patogenesis dan respon imun, serta faktor risiko tingkat keparahan dari COVID-19.

Pembahasan: Dari hasil pencarian literatur, didapatkan bahwa beberapa faktor yang paling sering diamati dan paling menentukan tingkat keparahan infeksi COVID-19 adalah usia, penyakit komorbid, defisiensi vitamin D, dan obesitas. Keempat faktor ini bukan merupakan faktor yang berdiri sendiri dalam menentukan tingkat keparahan infeksi COVID-19 namun merupakan faktor yang saling terkait dan saling mempengaruhi satu sama lain dalam menentukan tingkat keparahan infeksi COVID-19 dengan mekanismenya masing-masing.

Simpulan: Sebagian besar faktor yang menentukan tingkat keparahan COVID-19 merupakan faktor yang bisa dicegah. Hal ini membuat pengetahuan dan pemahaman klinisi mengenai faktor - faktor apa saja yang paling sering menentukan tingkat keparahan infeksi COVID-19 akan sangat membantu mencegah munculnya manifestasi klinis yang berat pada pasien COVID-19.
\end{abstract}

Kata Kunci: COVID-19, Faktor Risiko, Manifestasi Klinis 


\title{
FACTORS RELATED TO THE SEVERITY OF CORONAVIRUS DISEASE 2019 (COVID-19) INFECTION: A LITERATURE REVIEW
}

\begin{abstract}
Background: COVID-19 pandemic that started in the early 2020 triggers the declaration of Public Health Emergency of International Concern (PHEIC) by WHO. Caused by SARS-CoV-2 virus, COVID-19 mainly infects the respiratory tract by binding to the ACE2 receptor. COVID-19 infection can cause many clinical manifestations from no symptom to severe life-threatening symptom depending on many factors. Factors that can determine the severity of clinical manifestation is urgently needed to be recognized by our clinician in order to be able to anticipate patient's condition before the severe clinical manifestation even begins. This literature review is aimed to summarize and discuss some factors that are most often showed up and determined the severity of COVID-19 infection.

Methods: This literature review uses journal article that are sourced from online databases such as PubMed and Google Scholar. The type of article that will be chosen are research article, systematic review and meta-analysis, narrative review, and literature review with the topic of transmission, clinical manifestation, pathogenesis, immune response, and severity risk factor of COVID-19.
\end{abstract}

Discussion: From our literature search, it is concluded that the factors that are most likely to determine the severity of COVID-19 infection is age, comorbid disease, vitamin $D$ deficiency, and obesity. These four factors are not four independent factors but rather overlapping and interconnecting factors that determines the severity of COVID-19 infection.

Conclusion: Most of the factors that determined the severity of COVID-19 mainly are easily preventable factors. Therefore, the knowledge and awareness of our clinician about these factors will really help anticipating the severe clinical manifestation among COVID-19 patients before the manifestation even starts to appear.

Keywords: COVID-19, Clinical Manifestation, Risk Factors

\section{PENDAHULUAN}

Coronavirus Diseases-19 (COVID-19) masih menjadi perhatian seluruh dunia hingga saat ini. Coronavirus Diseases-19 (COVID-19) yang disebabkan oleh infeksi severe acute respiratory syndrome coronavirus 2 (SARS-CoV-2) terjadi pertama kali di Kota Wuhan, Provinsi Hubei, China pada akhir tahun $2019{ }^{[1]}$. Berdasarkan data yang dilansir oleh Johns Hopkins Coronavirus Resource Center (2021), hingga tanggal 13 Maret 2021 terdapat 20 negara yang saat ini sangat terpengaruh oleh COVID-19 di seluruh dunia. Grafik batang di bawah ini menunjukkan jumlah kematian baik per 100 kasus yang terkonfirmasi atau per 100.000 populasi. Persentase kematian tertinggi yaitu $9.0 \%$ terdapat di Mexico, $4.1 \%$ di Bulgaria, $2.7 \%$ di Indonesia, hingga $1.4 \%$ di India ${ }^{[2]}$.
Coronavirus Disease-19 (COVID19) merupakan kondisi yang disebabkan oleh virus SARS-CoV-2 dengan gejala yang beragam. Spektrum penyakit yang muncul pada infeksi COVID-19 dapat dibagi menjadi infeksi asimptomatik atau presimptomatik, gejala ringan, gejala sedang, gejala berat, dan gejala kritis ${ }^{[3]}$. Infeksi asimptomatik atau presimptomatik ditandai dengan hasil positif pada pemeriksaan penunjang namun tidak menunjukkan gejala apapun, gejala ringan ditandai dengan demam, batuk ringan, rasa tidak nyaman di tenggorokan, pusing, lemas, mual, muntah, diare, dan kehilangan kemampuan mengecap. Sedangkan, gejala sedang ditandai dengan adanya bukti infeksi saluran nafas bawah dengan saturasi $\mathrm{O}_{2}$ lebih dari $94 \%$ dan gejala berat ditandai dengan gejala sedang namun memiliki saturasi $\mathrm{O}_{2}$ yang kurang dari $94 \%{ }^{[4]}$. Seorang pasien 
COVID-19 akan dikategorikan sebagai gejala kritis jika pasien tersebut jika sudah terjadi Acute Respiratory Disease Syndrome (ARDS) atau syok sepsis. Mayoritas gejala yang dirasakan akan berlangsung selama kurang lebih 14 hari. Pada kebanyakan pasien, gejala pertama baru ditemukan pada hari ke-4 infeksi dengan gejala pertama yang tersering adalah keluhan demam disertai batuk kering, lalu dilanjutkan dengan gejala lain seperti sesak yang akan muncul setelah empat hari gejala awal muncul. Kondisi kegawatdaruratan ditandai dengan ARDS, sepsis, dan Acute Kidney Injury yang pada kebanyakan pasien akan berlangsung pada hari ke-7 hingga hari ke-19 [4],[5] .

Perbedaan manifestasi klinis dari COVID-19 merupakan hasil interaksi antara kerentanan individu tersebut dengan kemampuan (baik kualitas maupun kuantitas) dari virus untuk menginfeksi. Hingga saat ini, telah disepakati bahwa penyakit penyerta yang diderita oleh seorang individu mampu meningkatkan kerentanan seseorang sehingga akan menimbulkan manifestasi klinis yang parah. Beberapa penyakit penyerta yang sering dibahas adalah penyakit kardiovaskular, diabetes mellitus, serta kondisi nutrisional yang dimiliki oleh seorang individu. Namun, hingga saat ini masih belum ada artikel yang merangkum sejauh mana pemahaman dan penelitian terkait bukti dari masing masing penyakit tersebut memnpengaruhi manifestasi klinis yang muncul sebagai akibat dari infeksi virus ini ${ }^{[6]}$.

Pasar Grosir Makanan Laut Huanan di Wuhan ditengarai memiliki keterkaitan dengan kasus-kasus awal penularan COVID-19. SARS-Cov-2 kemungkinan ditularkan dari hewan ke manusia. Namun, studi genom memberikan bukti bahwa virus tersebut berasal dari tempat lain yang asalnya belum diketahui, Ialu ditularkan dari manusia ke manusia dan menyebar cepat pertama kali di pasar tersebut [1] Penularan dari manusia ke manusia dikonfirmasi menjadi transmisi utama sehingga penularannya menjadi lebih agresif dan ditularkan terutama melalui droplet dari pasien simtomatik yang keluar saat batuk atau bersin ${ }^{[7]}$. WHO memperkirakan reproductive number (Ro) COVID-19 sebesar 1,4 hingga 2,5. Namun, dalam analisis lebih lanjut dari 12 studi ditemukan bahwa $R_{0}$ adalah 3,28 dan Ro mungkin tidak stabil selama fase akut wabah atau prapandemi ${ }^{[1]}$.

SARS-CoV-2 memiliki stabilitas pada benda mati tidak jauh berbeda dari SARS-CoV. SARS-CoV-2 ditemukan lebih stabil pada bahan plastik dan stainless steel (>72 jam) daripada kardus (24 jam) dan tembaga (4 jam). Virus dapat dideteksi pada barangbarang dengan bahan tersebut namun tidak pada sampel udara [7]. Virus ini merupakan salah satu penyebab penyakit zoonosis yang mematikan. Inang perantara tentu sangat berpengaruh dalam penularan ke spesies lainnya karena mereka akan memfasilitasi adanya kontak antara virus dan sel inang baru dan memungkinkan adanya adaptasi lebih lanjut ${ }^{[1]}$.

Pada manusia, SARS-CoV-2 terutama menginfeksi sel di saluran nafas yang melapisi alveoli. Hal ini utamanya mengingat fakta bahwa glikoprotein yang terdapat pada envelope spike virus mampu berikatan dengan reseptor seluler ACE2 pada SARS-CoV-2. Di dalam sel epitel alveoli, SARS-CoV-2 mereplikasi materi genetik dan menyintesis protein yang dibutuhkan, kemudian membentuk virion baru yang muncul di permukaan sel ${ }^{[4]}$. Selain itu, identifikasi beberapa residu kunci (Gln493 dan Asn501) yang mengatur pengikatan domain pengikatan reseptor SARS-CoV-2 dengan ACE2 mendukung lebih lanjut bahwa SARS-CoV-2 memiliki kemampuan untuk penularan dari orang ke orang ${ }^{[1]}$. Setelah mengikat reseptorreseptornya, SARS-CoV-2 memasuki sel inang dan akan menghadapi respons imun bawaan dari tubuh inang. Untuk menginfeksi inang tersebut secara produktif, SARS-CoV-2 harus mampu menghambat atau menghindari sinyal imun bawaan inang. Sistem kekebalan tubuh akan merespons infeksi virus dengan mediasi peradangan dan aktivitas antivirus seluler dengan 
harapan dapat mampu menghambat replikasi dan penyebaran virus baik di dalam tubuh ataupun keluar dari tubuh dan menularkan individu lain ${ }^{[1]}$.

Memiliki kedekatan taksonomi yang sangat erat, penderita SARS dan COVID-19 memiliki pola kerusakan inflamasi yang serupa. Dalam serum dari pasien yang terdiagnosis dengan SARS, terjadi peningkatan kadar sitokin proinflamasi, misalnya, interleukin (IL)1, IL6, IL12, interferon gamma (IFN), IFN-induced protein 10 (IP10), protein inflamasi makrofag 1A (MIP1A) dan Monocyte Chemoattractant Protein-1 (MCP1)), yang berhubungan dengan inflamasi paru dan kerusakan parah paru-paru [1],[3]. Sejalan dengan itu, peningkatan serupa juga didapatkan pada pasien yang terdiagnosis COVID19.

Semenjak menyatakan kondisi pandemi global, WHO telah merekomendasikan untuk menerapkan edukasi, isolasi, pencegahan, dan pengendalian penyebaran virus serta penanganan bagi individu yang telah terjangkit [8]. Menurut Kemenkes RI (2021), pencegahan COVID-19 dapat dilakukan dengan cara menerapkan 5M (Memakai masker, Menjaga jarak, Mencuci tangan, Menghindari kerumunan, dan Mengurangi mobilitas). Walaupun sudah memakai masker, kita harus tetap menjaga jarak minimal 1 meter dengan orang lain dan tetep mencuci tangan dengan benar secara teratur [9]. Selain itu, mengingat kemampuannya untuk bertahan hidup dalam kondisi infeksius pada benda mati, direkomendasikan juga untuk secara rutin mensterilkan segala barang yang bersentuhan atau berpotensi berkontak dengan virus ini ${ }^{[8],[9]}$.

Hingga saat ini, telah terdapat berbagai literatur yang melaporkan dan membahas tentang manifestasi klinis dari COVID-19 baik yang ringan maupun yang berat dan faktor-faktor yang berkaitan dengan masing masing manifestasi klinis tersebut. Namun, masih sangat minim literatur yang meninjau secara gambaran besar mengenai faktor-faktor apa saja yang terbukti memiliki keterkaitan dengan tingkat keparahan manifestasi klinis dari
COVID-19. Oleh karena itu, melalui tinjauan pustaka ini, penulis ingin meninjau secara gambaran besar faktor - faktor yang berkaitan dengan tingkat keparahan COVID-19 menggunakan berbagai literatur yang tersedia saat ini.

\section{METODE}

Tinjauan pustaka ini menggunakan berbagai jenis sumber yang didapatkan dari jurnal ilmiah dan pedomanpedoman yang dikeluarkan oleh pemerintah ataupun instansi terkait. Sumber-sumber tersebut dicari melalui pusat data daring atau database yaitu PubMed dan Google Scholar menggunakan kata kunci (COVID-19 OR 2019-nCov OR "Coronavirus Disease") AND (Old OR Elder) AND (Mortality OR "Death Rate") AND ("Risk Factor") dengan hasil penelusuran berjumlah 43 jurnal dari PubMed dan 29 jurnal dari Google Scholar.

Artikel yang dipilih berupa artikel penelitian, systematic literature review dan meta-analysis, serta narrative review terfokus pada transmisi, manifestasi klinis, patogenesis dan respon imun, serta faktor risiko tingkat keparahan dari COVID-19. Pencarian literatur dibatasi pada publikasi berbahasa Inggris dan Indonesia, free full text dengan tahun jurnal 2019-2021. Total jurnal yang dimasukkan yaitu sebanyak dua puluh dua (22) artikel jurnal ke dalam literature review ini.

\section{PEMBAHASAN}

Berdasarkan dua puluh dua artikel jurnal yang didapatkan dari pencarian literatur, didapatkan beberapa faktor yang terbukti paling sering memiliki keterkaitan dengan tingkat keparahan infeksi COVID-19 yaitu usia, penyakit komorbid, defisiensi vitamin $\mathrm{D}$, dan obesitas yang dimiliki oleh pasien.

Usia sangat memengaruhi derajat keparahan penyakit dan mortalitas pada pasien COVID-19 [10]. Usia yang memiliki tingkat keparahan yang tinggi terjadi pada orang lanjut usia yaitu individu yang berumur 60 tahun ke atas [1]. Hal tersebut diduga dikarenakan oleh kompetensi sistem imun seseorang akan semakin berkurang seiring bertambahnya usia [11]. Penurunan 
kompetensi sistem imun ini disebabkan oleh terjadinya degenerasi pada seluruh komponen sistem imun bawaan dan sistem imun adaptif ${ }^{[12]}$. Degenerasi ini bermanifestasi dalam dua bentuk yaitu penurunan kuantitas selular (sel neutrofil, sel limfosit $T$, dan sel dendritik), penurunan jumlah reseptor yang terlibat dalam respon imun (reseptor TLR dan reseptor permukaan sel monosit dan makrofag), penurunan kemampuan untuk berdiferensiasi (sel limfosit B). Di sisi lain, individu dengan usia 15 tahun ke bawah memiliki kemungkinan yang lebih kecil untuk terinfeksi COVID-19 dikarenakan belum terjadinya degenerasi kompetensi sistem imun dan bahkan berbagai penelitian menunjukkan bahwa usia anak-anak hingga remaja merupakan titik puncak dari kompetensi sistem imun [13]. Hal ini didukung dengan suatu systematic review yang dipublikasikan pada akhir tahun 2020 yang merangkum berbagai gejala yang muncul pada infeksi COVID-19 di populasi anak-anak dan remaja. Artikel tersebut mendapatkan bahwa gejala yang diderita oleh anak-anak dan remaja yang terinfeksi COVID-19 akan lebih ringan dari pada orang dewasa ${ }^{[1],[14]}$.

Faktor kedua yang tidak kalah penting adalah penyakit penyerta yang dimiliki oleh individu yang terinfeksi COVID-19 terutama penyakit kardiovaskular, hipertensi, diabetes, dan gangguan hepar juga terbukti memperparah infeksi COVID-19. Artikel systematic review yang dipublikasikan pada tahun 2020 yang membahas tentang korelasi antara penyakit kronis yang menyertai individu yang terinfeksi dengan tingkat keparahan infeksi COVID-19 menunjukkan bahwa orang yang memiliki penyakit penyerta, terutama yang merupakan penyakit kronik, lebih rentan ternfeksi COVID-19 dan memiliki kemungkinan yang lebih tinggi untuk menimbulkan manifestasi

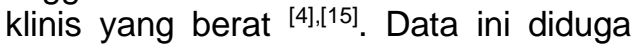
memiliki keterkaitan dengan faktor yang dibahas sebelumnya yaitu mengenai kompetensi sistem imun [15]. Hal ini mengingat fakta bahwa orang yang memiliki penyakit penyerta yang bersifat kronik akan terjadi penurunan terhadap respon imun mereka, sehingga lebih mudah terinfeksi oleh COVID-19 dan dapat mengalami luaran yang buruk ${ }^{[4]}$. Artikel tersebut mendapatkan bahwa odds ratio seseorang yang memiliki hipertensi untuk memunculkan manifestasi klinis yang lebih berat adalah sebesar 4,18 [15]. Selain itu, penyakit penyerta yang dimiliki oleh seseorang juga meningkatkan odds ratio untuk dirawat di ICU yang menandakan bahwa manifestasi klinis yang muncul sebagai konsekuensi dari infeksi COVID-19 cukup berat.

Peningkatan risiko keparahan COVID-19 juga berkaitan dengan defisiensi vitamin $D$ yang dialami oleh seseorang. Artikel systematic review yang dipublikasikan pada tahun 2020 menyimpulkan bahwa pasien COVID-19 yang mengalami defisiensi vitamin $D$, mengalami peningkatan kemungkinan untuk menimbulkan manifestasi klinis yang berat dan membutuhkan perawatan intensif di rumah sakit jika dibandingkan dengan orang yang tidak memiliki defisiensi vitamin $D^{[16]}$. Namun, peningkatan derajat keparahan ini tidak diiringi dengan peningkatan infection rate yang menunjukkan bahwa defisiensi vitamin $D$ tidak meningkatkan kerentanan seseorang untuk terinfeksi COVID-19 secara signifikan namun hanya terkait dengan manifestasi klinis yang ditimbulkan oleh infeksi COVID-19 setelah infeksi tersebut terjadi. Namun, pada artikel systematic review yang berbeda, didapatkan bahwa defisiensi vitamin $D$ memiliki keterkaitan dengan kerentanan seseorang untuk terjangkit COVID-19 [17]. Artikel tersebut mendapatkan bahwa odds ratio seseorang yang memiliiki defisiensi vitamin $D$ untuk mengalami manifestasi klinis dari COVID-19 yang berat adalah sebesar 1,95 yang menandakan bahwa adanya peningkatan risiko yang sangat signifikan. Perbedaan ini diduga dikarenakan adanya perbedaan dalam metode sampling dan metode pengukuran kadar vitamin $D$ pada berbagai penelitian yang dilibatkan dalam kedua artikel tersebut yang berbeda. Namun, satu hal yang samasama didapatkan oleh kedua artikel tersebut beserta berbagai artikel lain 
adalah bahwa defisiensi vitamin $D$ memiliki korelasi yang sangat kuat dengan manifestasi klinis yang ditimbulkan setelah terjadinya infeksi COVID-19 [16-18]. Mekanisme pasti yang mendasari data yang didapatkan ini memang hingga saat ini masih terus diteliti. Namun, terdapat satu dugaan kuat bahwa mekanisme tersebut melibatkan fakta bahwa kadar vitamin D berkebalikan dengan kadar sitokin proinflamasi yang menjadi salah satu penyebab utama munculnya manifestasi klinis berat pada infeksi COVID-19 $[16,18]$. Sejalan dengan pembahasan pada faktor sebelumnya, defisiensi vitamin D cenderung lebih sering terjadi pada individu lanjut usia, pasien dengan hipertensi, diabetes, dan obesitas yang semuanya berkaitan dengan peningkatan risiko dan keparahan COVID-19 sehingga semua faktor yang telah terbahas sebelumnya bukan merupakan faktor yang berdiri sendiri namun saling berkaitan satu sama lain dalam menentukan tingkat keparahan infeksi COVID-19 [19].

Obesitas juga merupakan salah satu kondisi yang sering dikaitkan dengan peningkatan risiko infeksi bahkan kematian COVID-19. Obesitas mampu menimbulkan efek buruk pada fungsi paru-paru terlepas dari konsekuensi kardiovaskular, metabolik, dan trombotik. Obesitas memberi efek negatif terhadap forced expiratory volume maupun forced vital capacity paru-paru. Pada kondisi obesitas ekstrem (IMT>40 kg/m²), sulit dilakukan tindakan imaging, ventilasi, maupun rehabilitasi pada pasien-pasien ICU [20]. Literatur tinjauan sistematis yang dipublikasikan pada tahun 2020 mengonfirmasi bahwa obesitas atau peningkatan IMT mampu meningkatkan risiko seseorang yang terinfeksi COVID19 untuk membutuhkan perawatan intensif di rumah sakit [21]. Sejalan dengan data tersebut, beberapa metaanalysis juga menunjukkan bahwa pasien obesitas dengan COVID-19 mengalami peningkatan risiko untuk menimbulkan manifestasi klinis yang lebih berat [22],[23]. Didapatkan terjadi peningkatan risiko sebesar $76 \%$ pada orang yang mengalami obesitas terhadap manifestasi berat dari infeksi COVID-19 dengan peningkatan hingga lebih dari dua kali lipat pada tingkat admisi ICU. Meskipun mekanisme yang mendasari hubungan tersebut masih merupakan hipotesis potensial yang mengaitkan pengaruh obesitas terhadap COVID-19, secara keseluruhan obesitas menurunkan reserve kardiorespirasi, mengakibatkan disregulasi metabolikinflamasi sistemik, serta meningkatkan risiko terjadinya trombosis. Semua hal itu berpotensi memperburuk luaran COVID-19 [20].

\section{KESIMPULAN}

Coronavirus Disease-19 (COVID19) merupakan suatu penyakit yang saat ini menyebabkan pandemi di seluruh dunia. Penularan yang cepat dan masih minimnya pengetahuan mendalam tentang virus ini dan penyakit yang ditimbulkannya membuat penanganan pada pasien masih kurang maksimal sehingga angka kematian atau mortality rate saat ini sangatlah tinggi. Sebagian besar faktor yang mempengaruhi tingkat keparahan infeksi COVID-19 merupakan faktor yang sangat memungkinkan untuk ditangani sehingga dapat mencegah munculnya manifestasi klinis yang berat. Hal tersebut membuat faktor-faktor yang menentukan tingkat keparahan infeksi sangat perlu diperhatikan karena akan menentukan tingkat keselamatan pasien serta membuat klinisi sadar akan halhal yang perlu diperhatikan, diantisipasi, dan ditangani secara dini pada pasien COVID-19 sebelum manifestasi klinis yang berat muncul mulai dari faktor usia, penyakit komorbid, defisiensi vitamin D, dan obesitas pada pasien.

\section{DAFTAR PUSTAKA}

1. Harapan $\mathrm{H}$, Itoh $\mathrm{N}$, Yufika $A$, Winardi W, Keam S, Te H, et al. Coronavirus disease 2019 (COVID19): A literature review. J Infect Public Health 2020;13(5):667-73.

2. Noor AU, Maqbool F, Bhatti ZA, Khan AU. Epidemiology of CoViD19 Pandemic: Recovery and mortality ratio around the globe. Pakistan J Med [Internet] 220AD;36(4):S79-84. Available 
from:

https://www.ncbi.nlm.nih.gov/pmc/ar ticles/PMC7306958/

3. Esakandari E, Afjadi MN, Afjadi JF, Farahmandian N, Miresmaeili SM, Bahreini E. A comprehensive review of COVID-19 characteristics. Biol Proced Online [Internet] 2020;22(19). Available from: https://www.ncbi.nlm.nih.gov/pmc/ar ticles/PMC7402395/

4. Susilo $A$, Rumende CM, Pitoyo CW, Santoso WD, Yulianti M,

Herikurniawan $\mathrm{H}$, et al. Coronavirus Disease 2019: Tinjauan Literatur Terkini. J Penyakit Dalam Indones 2020;7(1):45.

5. Fi L, Wan B, Yuan T, Chen X, Ao Y, Fitzpatrick T, et al. Clinical characteristics of coronavirus disease 2019 (COVID-19) in China: A systematic review and metaanalysis. J Infect Dis 2020;80(6):656-65.

6. Sanyaolu A, Okorie C, Marinkovic A, Patidar R, Younis K, Hosein Z, et al. Comorbidity and its Impact on Patients with COVID-19. SN Compr Clin Med [Internet] 2020;1-8.

Available from: https://www.ncbi.nlm.nih.gov/pmc/ar ticles/PMC7314621/\#

7. Ikawaty R. Dinamika Interaksi Reseptor ACE2 dan SARS-CoV-2 Terhadap Manifestasi Klinis COVID19. KELUWIH J Kesehat dan Kedokt 2020;1(2):70-6.

8. Lotfi M, Hamblin MR, Rezaej N. COVID-19: Transmission, prevention, and potential therapeutic opportunities. Clin Chim Acta [Internet] 2020;508:254-66. Available from: https://www.ncbi.nlm.nih.gov/pmc/ar ticles/PMC7256510/

9. WHO. Pedoman Menggunakan Masker. 2021;

10. Lee PI, Hu YL, Chen PY, Huang YC, Hsueh PR. Are children less susceptible to COVID-19? J Microbiol Immunol Infect 2020;53(3):371-2.

11. Zheng Z, Peng F, Xu B, Zhao J, Liu $\mathrm{H}$, Peng J. Since January 2020 Elsevier has created a COVID-19 resource centre with free information in English and Mandarin on the novel coronavirus COVID- 19 . The COVID-19 resource centre is hosted on Elsevier Connect , the company ' $s$ public news and information . 2020;(January).

12. Oh S-J, Lee JK, Shin OS. Aging and the Immune System: the Impact of Immunosenescence on Viral Infection, Immunity and Vaccine Immunogenicity. Immune Netw [Internet] 2019;19(6):e37. Available from:

https://www.ncbi.nlm.nih.gov/pmc/ar ticles/PMC6943173/

13. Simon AK, Hollander GA, McMichael A. Evolution of the immune system in humans from infancy to old age. Proc Biol Sci [Internet] 2015;282(1821):20143085.

Available from: https://www.ncbi.nlm.nih.gov/pmc/ar ticles/PMC4707740/

14. Viner RM, Ward JL, Hudson LD, Ashe M, Patel SV, Hargreaves D, et al. Systematic review of reviews of symptoms and signs of COVID-19 in children and adolescents. Arch Dis Child [Internet] 2020;archdischi. Available from: https://www.ncbi.nlm.nih.gov/pmc/ar ticles/PMC7747494/

15. Liu H, Chen S, Liu M, Nie H, Li H. Comorbid Chronic Diseases are Strongly Correlated with Disease Severity among COVID-19 Patients: A Systematic Review and MetaAnalysis. Aging Dis [Internet] 2020;11(3):668-78. Available from: https://www.ncbi.nlm.nih.gov/pmc/ar ticles/PMC7220287/

16. Pereira M, Damascena AD, Azevedo LMG, Oliveira T de A, Santana $\mathrm{J}$ da M. Vitamin D deficiency aggravates COVID-19: systematic review and metaanalysis. Crit Rev Fooc Sci Nutr [Internet] 2020;4:1-9. Available from:

https://pubmed.ncbi.nlm.nih.gov/331 46028/

17. Yisak $H$, Ewunetei $A$, Kefale $B$, Mamuye B, Mamuye M, Teshome F, et al. Effects of Vitamin D on COVID-19 Infection and Prognosis: 
A Systematic Review. Risk Manag Healthc Policy [Internet] 2021;14:31-8. Available from: https://www.ncbi.nlm.nih.gov/pmc/ar ticles/PMC7800698/

18. Weir EK, Thenappan T, Chen Y. Does vitamin $D$ deficiency increase the severity of COVID-19? Clin Med (Royal Coll Physician London) [Internet] 2020;20(4):e107-8. Available from: https://www.ncbi.nlm.nih.gov/pmc/ar ticles/PMC7385774/

19. Febriana L. Potensi Suplemen dalam Tatalaksana COVID-19. 2021;48(2):93-6.

20. Sattar N, Mclnnes IB, McMurray JJV. Obesity Is a Risk Factor for Severe COVID-19 Infection: Multiple Potential Mechanisms. Circulation 2020;4-6.

21. Huang $Y$, Lu Y, Huang Y-M, Wang $M$, Ling $W$, Sui $Y$, et al. Obesity in patients with COVID-19: a systematic review and metaanalysis. Metabolism [Internet] 2020;113:154378. Available from: https://www.ncbi.nlm.nih.gov/pmc/ar ticles/PMC7521361/

22. Chu Y, Yang J, Shi J, Zhang $P$, Wang $X$. Obesity is associated with increased severity of disease in COVID-19 pneumonia: a systematic review and meta-analysis. Eur $\mathrm{J}$ Med Res [Internet] 2020;25:64. Available from: https://www.ncbi.nlm.nih.gov/pmc/ar ticles/PMC7708895/

23. Malik VS, Ravindra K, Attri SV, Bhadada SK, Singh M. Higher body mass index is an important risk factor in COVID-19 patients: a systematic review and metaanalysis. Environ Sci Pollut Reserach Int [Internet] 2020;2020:1-9. Available from: https://www.ncbi.nlm.nih.gov/pmc/ar ticles/PMC7380664/ 